\title{
Original article (short paper) \\ Design, validation, and reliability of survey to measure female athlete triad knowledge among coaches
}

\author{
Jillian E. Frideres \\ Universidad de Murcia, Murcia, Spain \\ Sue G. Mottinger \\ University of Texas Pan American, Edinburg, TX, United States \\ José M. Palao \\ Universidad de Murcia, Murcia, Spain
}

\begin{abstract}
The purpose of this study was to design and to test the validity and reliability of an instrument to evaluate coaches' knowledge about the female athlete triad syndrome and their confidence in this knowledge. The instrument collects information regarding: knowledge of the syndrome, components, prevention and intervention; confidence of the coaches in their answers; and coach's characteristics (gender, degree held, years of experience in coaching females, continuing education participation specific to the syndrome and its components, and sport coached). The process of designing the questionnaire and testing the validity and reliability of it was done in four phases: a) design and development of the instrument, b) content validity, c) instrument reliability, and d) concurrent validity. The results show that the instrument is suitable for measuring coaches' female athlete triad knowledge. The instrument can contribute to assessing the coaches' knowledge level in relation to this topic.
\end{abstract}

Keywords: sport, health, prevention, evaluation

Resumo - "Desenho, validação e fiabilidade da pesquisa para avaliar o conhecimento dos treinadores sobre a tríade da mulher atleta." O objetivo do estudo foi desenhar e testar a validação e fiabilidade do instrumento para avaliar o conhecimento que os treinadores possuem acerca da tríade da mulher atleta. O instrumento de coleta de informações sobre: conhecimento da tríade, componentes, prevenção e intervenção; confiança dos treinadores em suas respostas; características dos treinadores (gênero, formação acadêmica, anos de experiência em treino com atletas femininas, participação em formações específicas na tríade e componentes da tríade e treino desportivo). O desenho e o teste de validação e fiabilidade do questionário foram realizados em quatro fases: a) desenho e desenvolvimento do instrumento; b) validação do conteúdo; c) fiabilidade do instrumento e; d) validade concorrente. Os resultados mostraram que o instrumento é adequado para mensurar o conhecimento dos treinadores sobre a tríade da mulher atleta. $\mathrm{O}$ instrumento pode contribuir para a avaliação do nível de conhecimento dos treinadores relativamente ao tema.

Palavras-chave: desporto, saúde, prevenção, avaliação

Resumen - "Diseño, validez, y fiabilidad de un instrumento para medir el conocimiento sobre la triada atlética femenina en entrenadores." El objetivo del este estudio fue diseñar y comprobar la validez y fiabilidad de un instrumento para evaluar el conocimiento sobre el síndrome de la triada atlética femenina y la confianza de su conocimiento que los entrenadores tienen. El instrumento recoge información sobre: conocimiento sobre el síndrome, componentes, prevención e intervención; confianza de los entrenadores en sus respuestas, y las características de los entrenadores (género, formación, años de experiencia entrenando mujeres, participación en programas de formación sobre la triada y sus componentes, y deporte que entrenan). El diseño y comprobación de la validez y fiabilidad del cuestionario se realizó en cuatro fases: a) diseño y desarrollo del instrumento, b) validación de contenidos; c) fiabilidad del instrumento; y d) validez concurrente. Los resultados muestran que el instrumento es adecuado para valorar el conocimiento de los entrenadores sobre el síndrome de la triada atlética femenina. El instrumento puede contribuir a valorar el conocimiento de los entrenadores con respecto a este tema.

Palabras claves: deporte, salud, prevención, evaluación 


\section{Introduction}

The "female athlete triad" syndrome involves three components: low energy availability, sometimes associated with disordered eating, menstrual dysfunction, and low bone mineral density (Barrack, Ackerman, \& Gibbs, 2013; Hobart, 2000; Otis, Drinkwater, Johnson, Loucks, \& Wilmore, 1997; Smith, 1996). This syndrome often starts when an athlete consciously or unconsciously decreases her caloric intake or increases her energy expenditure (Sundgot-Borgen, 1994). As a result of low energy availability, menstrual function is altered (Barrack, Ackerman, \& Gibbs, 2013; Otis et al., 1997; Rust, 2002). The decreased estrogen level leads to lower bone mineral density, osteopenia or osteoporosis. The female athlete triad syndrome can have serious long-term consequences (e.g. pathogenic behaviors, full-fledged eating disorders, hormonal issues, and loss of bone density) for which treatment can be difficult (Thompson $\&$ Gabriel, 2004). The ideal treatment plan is multdisciplinary in nature. Thus, prevention is widely regarded as the key to combating the syndrome (Beals, Brey, \& Gonyou, 1999; Joy, et al., 1997a; Rust, 2002). Prevention is where coaches can play an important role. Coaches create the training environment and they are a key piece in preventive measures or screening (Eagle, Lohman, \& Jarman, 2013; Joy et al., 1997a; Sherman, Thompson, Dehass, \& Wilfert, 2005).

The female athlete triad syndrome is a relatively new issue. It is not clear what coaches know about the syndrome (low energy availability, menstrual dysfunction, and low bone mineral density), its effects, risk factors, or their roles as coaches in the prevention of this syndrome. Along these lines, some national governing bodies have considered mandatory education for coaches (governing bodies not cited; Joy et al., 1997b). Previous research has been focused on coaches' knowledge regarding nutrition, parts of the triad, or their attitudes or actions (Froiland, Koszewski, Hingst, \& Kopecky, 2004; Jacobson, Sobonya, \& Ransone, 2001; Joy et al., 1997a; Juzwiak \& Ancona-Lopez, 2004; Pantano, 2006; Sossin et al., 1997; Troy, Hoch, \& Stavrakos, 2006). These studies shows coaches are aware of the menstrual problems of their athletes and identified more symptomatic athletes (Sherman, et al., 2005) but also that they recommend dangerous weight control practices (Juzwiak \& Ancona-Lopez, 2004). Further, some coaches do not have enough knowledge about the syndrome (Troy, et al., 2006; Pantano, 2006). Thus, it is not clear whether coaches are prepared to provide information and to set proper and safe training environments for their athletes and teams.

Information regarding what coaches know about the syndrome is critical for establishing the need for specific training on the issue and the characteristics of the training program. Most instruments used to measure coaches' knowledge involve asking coaches about the perceptions of their knowledge, including few questions about the syndrome, or they focus on one of the components (low energy availability, menstrual dysfunction, or low bone mineral density) or aspects (effects, signs, or recognition) of the syndrome. Carrying out educational programs and monitoring coaches' knowledge needs require an instrument to measure this knowledge at different levels, such as the syndrome, its components (characteristics and effects), how to prevent it, and how to intervene. This instrument will allow us to establish whether coaches have the knowledge and training to assist in preventing and referring this problem or whether their specific continuing education program is working. To best estimate the coaches' receptiveness toward receiving training, the effect of the program, or the measurement of the application of the coaches' knowledge, an instrument should also evaluate the confidence that coaches have in their knowledge (Turk, Prentice, Chappell, \& Shields Jr,. 1999; Vaughan, King, \& Cottrell, 2004). Without confidence in one's knowledge, the step from knowledge to application is more difficult or even dangerous, as without accurate knowledge they can create risky situations (Wozney, Venkatesh, \& Abrami, 2006). This instrument can provide information about the factors influencing coaches' knowledge, such as sociodemographic characteristics, experiences, education, etc. Therefore, the purpose of this study was to design, validate, and test the reliability of an instrument to assess the knowledge that coaches have about the female athlete triad syndrome and the confidence they have in this knowledge.

\section{Methods}

\section{Sample}

The sample for the content validity was nine experts. All experts held a PhD, MD, or similar degree and had at least 5 years of experience carrying out research related to the female athlete triad syndrome or one of its components or treating female athletes. The experts were from the following fields: medicine/family practice, nutrition, physical therapy, gynecology, eating disorder recovery, triad research in athletes, coaching female athletes, and sport psychology.

The sample for the reliability test was 12 coaches. The characteristics of this group of coaches were: an average age of $39.4 \pm 11.2$ years, an average coaching experience at the college level of $11.3 \pm 7.7$ years, $41.6 \%$ were female, and all coaches had a university degree.

The sample for the concurrent validity were 45 college coaches from an endurance sport that emphasized weight control (cross-country) and 63 coaches from a sport that theoretically does not emphasize weight control (basketball) in the 20062007 season. All coaches were from the athletics department of an American Division I university. The characteristics of this group of cross country coaches were: an average age of $40.8 \pm 13.1$ years, an average coaching experience at the college level of $12.4 \pm 9.2$ years, $37.8 \%$ were female, and all coaches had a university degree. The characteristics of this group of basketball coaches were: an average age of $36.6 \pm 9.2$ years, an average coaching experience at the college level of $10.3 \pm 8.3$ years, 58.8\% were female, and all coaches had a university degree. The study was approved by the University of Texas-Pan American Institutional Review Board (IRB\#500; 2007/04/24). 


\section{Procedures}

There were four phases in the process of designing the questionnaire and testing the validity and reliability of it: a) design and development of the instrument, b) testing the content validity, c) testing the instrument reliability, and d) testing the concurrent validity (Trochim \& Donnelly, 2007).

The first phase, the design and development of the instrument, involved the use of specific literature about the female athlete triad syndrome and knowledge instruments related to the topic. Reviews in the following databases were done: Web of Knowledge (WOK) of ISI (Thomson), Medline, SPORTDiscus, Google Scholar, Sponet, Scielo, and Dialnet. The key word searches included: "female athlete triad," "eating disorders," "amenorrhea," "osteoporosis," "knowledge," and "coaches" (as well as equivalents in Portuguese and Spanish for the Scielo and Dialnet databases, respectively). Abstracts were reviewed to select the papers related to the female athlete triad syndrome. The criterion followed to select the article was that it studied coaches' or athletes' knowledge regarding the female athlete triad syndrome or its components. Several articles and surveys were selected from the literature regarding nutrition, the components of the syndrome, or coaches' attitudes or actions regarding the components of the syndrome (Beals, et al., 1999; Bradney, 2002; Hobart, 2000; Juzwiak \& Ancona-Lopez, 2004; Joy et al., 1997a; Joy et al., 1997b; Lassiter, 2002; Martínez-Pecino, Mulas-Sánchez, Fernández-Palacín, \& Bayón-Suárez, 1997; Sossin et al., 1997; Turk, 1995). After reviewing the bibliography, the parts and topics of the instrument were established (Table 1). Several instruments (Bradney, 2002; Lassiter, 2002; Martínez-Pecino, et al., 1997; Turk, 1995) and literature about creating an original instrument (Hague, Hague, \& Morgan, 2004; Thomas, 2004) were used as guides to design the instrument presented in this article.

From the review of the literature and the surveys that were used in empirical research that were found in the literature, the outline of the survey and the first draft of questions were established (Table 1). Questions were designed to ask about these aspects and about the coaches' characteristics. The aspects were grouped into: a) knowledge of the syndrome, components, prevention and intervention; b) coaches' confidence in their responses (coaches' perception of the adequacy of their answers); and c) coaches' characteristics (gender, degree held, years of experience in coaching females, continuing education participation specific to the syndrome and its components, and sport coached). Finally, questions about the sample's characteristics (ethnicity, number of coaches in their program, experience, level of competition, sport, and formal training) were also included. For the questions related to sociodemographics of the coaches, multiple choice items were used, except for questions related to degree held, number of coaches in program, and number of years coaching females, where the possibility to type in the answer was given. For the questions related to knowledge, multiple choice, and true/false were used, depending on the objective. A 4-point Likert scale was provided to determine level of confidence: 1) not at all confident; 2) somewhat confident; 3) confident; and 4) completely sure.

The evaluation of the level of confidence was included to measure the confidence the coach had in his or her knowledge (Turk, 1995), as a low level of confidence has been related to a lack of application of one's knowledge (Bandura \& Wood, 1989). Knowledge and confidence level were taken into account to calculate the overall knowledge score. A correct answer with the highest confidence resulted in the highest weighted score for that question, while an incorrect answer with the highest confidence resulted in the lowest weighted score (Table 2). In fact, this score was lower than answering "don't know", as it is potentially dangerous to have inaccurate information but to believe that it is correct. The overall score was between -35.00 and 35.00.

In the second phase, nine experts in fields related to at least one of the components of the syndrome provided input regarding the instrument. The experts evaluated the qualitative (open questions) and quantitative questions (scale from 1 to 10) from the survey regarding: degree of definition and understanding of the survey's questions; degree of adequacy of the survey's questions, the scale used, and the need to include more questions in the survey. The collective suggestions from the experts were considered and the appropriate changes were made.

Table 1. Structure of the survey (parts and topics of the different questions of the survey) and references used to develop the survey.

\begin{tabular}{lc}
\hline \multicolumn{1}{c}{ Parts of the survey } & Survey question number(s) \\
\hline Coaches' information & $1-11^{267910}$ \\
Knowledge questions & $12-42$ \\
$\quad$ Definition of the syndrome and/or components & $12,17-19,21-22^{13710}$ \\
Effects of the syndrome and/or components & $14,20,23,24,30^{1367}$ \\
Population and incidence of the syndrome and/or components & $13,25^{137}$ \\
Risk factors and detection of the syndrome & $16,26^{234710}$ \\
Causes of the syndrome and/or components & $27,33^{1347910}$ \\
Signs and symptoms of the syndrome and/or components & $15,29,31^{1347910}$ \\
Prevention of the syndrome and/or components & $28,32,34-38^{15710}$ \\
Intervention & $39-42^{59}$ \\
Coaches' formation and continuing education & $43-50^{8910}$
\end{tabular}

${ }^{1}$ Beals, Brey, \& Gonyou (1999); ${ }^{2}$ Bradney (2002); ${ }^{3}$ Hobart (2000); ${ }^{4}$ Joy et al. (1997a); ${ }^{5}$ Joy et al. (1997b); 6 Juzwiak \& Ancona-López (2004); ${ }^{7}$ Lassiter (2002); ${ }^{8}$ Martínez-Pecino, et al. (1997); ${ }^{9}$ Sossin et al. (1997); ${ }^{10}$ Turk (1995). 
Table 2. Calculation of points for survey.

\begin{tabular}{|c|c|c|c|c|}
\hline \multirow[b]{2}{*}{ Given Answer } & \multicolumn{4}{|c|}{ Confidence } \\
\hline & 1 & 2 & 3 & 4 \\
\hline Correct answer & .25 & .50 & .75 & 1.0 \\
\hline \multirow[t]{2}{*}{ Incorrect answer } & -.25 & -.50 & -.75 & -1.0 \\
\hline & \multicolumn{4}{|c|}{ Don't know $=0$} \\
\hline
\end{tabular}

In the third phase, the reliability of the instrument was calculated. The questionnaire was sent to selected college coaches of an NCAA Division II program by e-mail. Twelve coaches completed the test-retest process. A final section allowing for comments took into consideration their understanding of the questionnaire, the time taken to complete the survey, and questions or concerns they had with the instrument. One week after completing the instrument, the questionnaire was sent back to the same sample of coaches for test-retest procedures for determining instrument reliability.

In the fourth phase, we measured the ability of the instrument to differentiate between coaches of different types of sport (Trochim \& Donnelly, 2007). The type of sport was established using the classification by Rust (2002). Forty-five coaches from an endurance sport that emphasized weight control (cross-country) and 63 coaches from a sport that theoretically does not emphasize weight control (basketball) were analyzed (20062007 season). The survey was sent to the coaches by e-mail. The coaches' e-mails were obtained from their websites. Fifty percent of NCAA Division I intercollegiate universities were selected randomly from the NCAA website. The response rate was $15 \%$ for cross country and $11.9 \%$ for basketball.

\section{Statistical analysis}

To test the content validity of the instrument, a descriptive analysis of coaches' responses (mean, median, and mode) was also done. Following Bulger and Housner (2007), questions with values lower than 7.0 were eliminated, questions with values between 7.1 and 8.0 were modified, and questions with values greater than 8.0 were accepted or accepted with modifications. With the values from the quantitative evaluation done by the experts, the Aiken's V was calculated (Penfield \& Giacobbi, 2004).

The reliability of each item of the instrument was calculated using the Kappa Index for each of the questions (categorical variables). To test the ability of the instrument to differentiate between coaches of different types of sport (concurrent validity), an inferential analysis of the data (one-factor ANOVA) was done to establish whether there were differences between coaches of both types of sport using the SPSS 15.0 software with a level of statistical significance set at $p<.05$.

\section{Results}

The draft of the survey had 48 questions after the first phase. The survey comprised three parts: a) 10 questions related to the coaches' characteristics, b) 30 questions related to knowledge of the syndrome, and c) 8 questions related to coaches' education and continuing education. The knowledge questions were subdivided into seven parts: a) definition of the syndrome and/or components, b) effects of the syndrome and/or components, c) population and incidence of the syndrome and/or components, d) risk factors and detection of the syndrome, e) causes of the syndrome and/or components, f) signs and symptoms of the syndrome and/or components, g) prevention of the syndrome and/or components, and $\mathrm{h}$ ) intervention.

After reviewing the experts' evaluation of the draft of the survey, one question related to knowledge was eliminated, three questions were added, two questions were merged, and 12 questions were modified. The experts' observations were related to the terms used, the need to clarify the terminology and questions, and expressing the questions and the scale in a positive way. All questions of the draft of the survey at this phase had an average score $>$ 7.0. Aiken's $\mathrm{V}$ from the quantitative evaluation of the experts was calculated. The Aiken's $V$ was pertinent ( $>.84$ for the lowest value).

From the score of the test-retest process that was carried out with 12 coaches of an NCAA Division II program, the total reliability of the questionnaire was calculated (the smallest of these calculations). An intra-class correlation coefficient of .68 was found. Regarding the ability of the instrument to differentiate theoretically different groups of coaches (Table 3 ), significant differences were found in the knowledge score of the coaches of an endurance sport that emphasizes weight and coaches of a sport that theoretically does not emphasize weight. Further, significant differences were found in the education received about this topic, this interest in this topic, and the coaches' involvement $(p<.000)$. The final version of the survey is included (Appendix).

Table 3. Knowledge score and average confidence based on type of sport coached.

\begin{tabular}{|c|c|c|c|c|}
\hline & \multicolumn{2}{|c|}{ Score } & \multicolumn{2}{|c|}{ Confidence } \\
\hline Type of sport & Average & Percentage & Average & Percentage \\
\hline Endurance sport that emphasizes weight & $18.24 * * *$ & 76.07 & $3.15 * * *$ & 78.70 \\
\hline Sport that does not emphasize weight & $12.93 * * *$ & 68.48 & $2.68 * * *$ & 67.12 \\
\hline
\end{tabular}

$* * * p<.000$ (One-factor ANOVA). 


\section{Discussion}

The results show that the instrument is suitable for measuring coaches' female athlete triad syndrome knowledge. Coaches have an important role in creating safe training environments and providing preventive measures or screening to reduce the incidence of the female athlete triad syndrome (Eagle, et al., 2013; Joy et al., 1997a; Sherman, et al., 2005). Given that this syndrome is a relatively new issue for coaches; the instrument can provide information about the coaches' knowledge about this topic. The instrument allows us to collect information regarding the coaches' characteristics, their education and continuing education, and about their specific knowledge about the female athlete triad syndrome (components, effects, risks, signs, causes, prevention, and intervention).

The instrument allows us to obtain information about coaches' knowledge regarding a basic perspective (definition, effects, or risks), regarding an applied perspective (how to detect environments that can foster the syndrome, signs and symptoms, prevention, and/or steps to take if a case is detected), and coaches' knowledge confidence. The knowledge about the coaches' confidence provides us information about their receptiveness as well as their knowledge perception. All this information can help us understand coaches' need for knowledge. The instrument can also be used to measure the effect of educational programs or to obtain information about the knowledge of coaches from different sports, levels, or characteristics. This information provides data that could be useful for planning and implementing educational training for the specific needs of these populations.

Specifically, regarding the validity and reliability process, the procedures that were followed combined the experts' evaluation with testing the instrument with a group of coaches. The coaches' evaluation involved qualitative and quantitative assessments of the instrument, thus allowing us to combine the advantages of both types of assessment. Their evaluations helped to develop the instrument by contributing to establishing the adequacy, level of understanding, and terminology (Bulger \& Housner, 2007; Escurra, 1989; Padilla, Gómez, Hidalgo \& Muñiz, 2007; Zhu et al., 1998). The experts positively evaluated the inclusion of the confidence in the questions to assess the coaches' perception about their knowledge.

The reliability of the instrument (test-retest procedure) was "substantial" and pertinent (Landis \& Koch, 1977). The value of the intra-class correlation coefficient that was found may be affected by coaches either doubting their responses after completing the survey or reviewing information about the topic. The reliability was tested with an online survey, as those were the conditions under which the survey was going to be administered in the future. However, this procedure may involve a lack of control over the conditions in which the coaches completed the survey. On the other hand, it was done in a more natural situation.

The findings regarding the concurrent validity show the ability of the instrument to differentiate between groups that, in theory, are different. Theoretically, coaches and athletes from sports with a higher incidence of the female athlete triad syndrome or some of its components should have received more information about it, be more aware of it, and have more experience with it (Eagle, et al., 2013; Joy et al., 1997a; Sherman, et al., 2005). The results show coaches of a sport with a higher incidence of the female athlete triad syndrome had higher knowledge scores as well as more confidence in their responses. However, these findings need to be carefully considered due to the response rate (11-15\%). The response rate was $15 \%$ lower than similar research (Pantano, 2006). These may demonstrate bias in the data, as only coaches interested in the topic may have responded. Still, findings would show differences between coaches interested in the topic in both sports.

The process that was followed and the data found show that this instrument is suitable for measuring coaches' female athlete triad syndrome knowledge in college coaches. This instrument can be used by researchers, athletic directors, and/ or coaches to evaluate the need for specific education as well as the effect of educational training done by the coaches. This instrument lets us monitor the knowledge of this topic, detect the need for education by coaches, and assess the effect of continuing education as well as the evolution of this knowledge over time. Performance sport involves the risk of developing unhealthy behaviors. The role of coaches must be proactive to avoid these problems. Knowledge of and involvement in prevention are key aspects in reducing health problems in sport. The instrument that was developed and validated in this paper can contribute to knowing how the coaches' knowledge level is related to this topic.

Limitations and future research

The instrument design and the processes of validation and reliability that were carried out are only the first steps in the process of developing an instrument due to these steps being carried out in a specific sample. Testing it in other populations, obtaining reference values, and translating it to other languages is needed. Coaches have an important role in the health of their athletes (Eagle, et al., 2013; Joy et al., 1997a; Sherman, et al., 2005). They must be aware of possible health issues. The present instrument can be used to obtain information regarding coaches' knowledge, to study the effect of specific educational training, or to study the relationship between knowledge and application (information provided, training environment, or stress perceived by athletes).

\section{References}

Bandura, A., \& Wood, R.E. (1989). Effects of perceived controllability and performance standards on self-regulation of complex decision -making. Journal of Personality and Social Psychology, 56, 805-814.

Barrack, M.T., Ackerman, K.E., \& Gibbs, J.C. (2013). Update on the female athlete triad. Current Reviews in Musculoskeletal Medicine, 6, 195-204.

Beals, K.A., Brey, R.A., \& Gonyou, J.B. (1999). Understanding the female athlete triad: Eating disorders, amenorrhea, and osteoporosis. The Journal of School Health, 69, 337-340.

Bradney, D. (2002). Attitudes of coaches regarding eating disorders. Unpublished doctoral dissertation, Springfield College, Springfield, MA.

Bulger, S.M., \& Housner, L.D. (2007) Modified Delphi investigation of exercise science in physical education teacher education. Journal 
of Teaching in Physical Education, 26, 57-80.

Eagle, S.R., Lohman, C., \& Jarman, N. (2013). Enhancing knowledge of nutrition and prevention in medical professionals and coaches: the key to defeating the Female Athlete Triad. Journal of Athletic Medicine, 1, 23-36.

Escurra, L. (1989). Cuantificación de la validez de contenido por criterio de jueces [Quantification of content validity through judge criteria]. Revista de Psicología, 6, 103-111.

Froiland, K., Koszewski, W., Hingst, J., \& Kopecky, L. (2004). Nutritional supplement use among college athletes and their sources of information. International Journal of Sport Nutrition and Exercise Metabolism, 14, 104-120.

Hague, P., Hague, N., \& Morgan, C. (2004). Market research in practice: A guide to the basics. London: Kogan Page.

Hobart, J.A. (2000). The female athlete triad. American Family Physician, 61, 3357-3364.

Jacobson, B.H., Sobonya, C., \& Ransone, J. (2001). Nutrition practice and knowledge of college varsity athletes: A follow-up. Journal of Strength and Conditioning Research, 15, 63-68.

Joy, E., Clark, N., Ireland, M. L., Martire, J., Nattiv, A., \& Varechok, S. (1997a). Team management of the female athlete triad: Part 1: What to look for, what to ask. The Physician and Sportsmedicine, 25, 94-102.

Joy, E., Clark, N., Ireland, M.L., Martire, J., Nattiv, A., \& Varechok, S. (1997b). Team management of the female athlete triad: Part 2: Optimal treatment and prevention tactics. The Physician and Sportsmedicine, 25, 55-64.

Juzwiak, C.R., \& Ancona-Lopez, F. (2004). Evaluation of nutrition knowledge and dietary recommendations by coaches of adolescent Brazilian athletes. Journal of Sport Nutrition and Exercise Metabolism, 14, 222-235.

Landis, J.R., \& Koch, G.G. (1977). The measurement of observer agreement for categorical data. Biometrics, 33, 159-174. doi: $10.2307 / 2529310$

Lassiter, J.W. (2002). A survey of student coaches' knowledge, attitudes, skills, and behaviors regarding the female athlete triad. Unpublished master's thesis, State University of New York College at Brockport.

Martínez-Pecino, M., Mulas, M.Y., Fernández, F., \& Bayón, F. (1997). Encuesta a los médicos internos residentes de rehabilitación sobre su formación. Rehabilitación, 31, 17-22.

Otis, C.L., Drinkwater, B., Johnson, M., Loucks, A., \& Wilmore, J. (1997). ACSM position stand: The female athlete triad. Medicine and Science in Sports and Exercise, 29, 1-9.

Padilla, J.L., Gómez, J., Hidalgo, M.D., \& Muñiz, J. (2007). Esquema conceptual y procedimientos para analizar la validez de las consecuencias del uso de los test [Conceptual diagram and procedures to analyze the validity of the consecuences of test use]. Psicothema, 19, 173-178.

Pantano, K.J. (2006) Current knowledge, perceptions, and interventions used by collegiate coaches in the US regarding the prevention and treatment of the female athlete triad. North American journal of sports physical therapy: NAJSPT, 1, 195.

Penfield, R.D., \& Giacobbi, P.R. (2004) Applying a score confidence interval to Aiken's item content-relevance index. Measurement in Physical Education and Exercise Science, 8, 213-225.

Rust, D.M. (2002). The female athlete triad: Disordered eating, amenorrhea, and osteoporosis. The Clearing House, 75, 301-305.

Sherman, R.T., Thompson, R.A., Dehass, D., \& Wilfert, M. (2005). NCAA coaches survey: The role of the coach in identifying and managing athletes with disordered eating. Eating Disorders, 13, 447-466.

Smith, A.D. (1996). The female athlete triad: Causes, diagnosis, and treatment. The Physician and Sportsmedicine, 24, 67-73.

Sossin, K., Gizis, F., Marquart, L.F., \& Sobal, J. (1997). Nutrition be- liefs, attitudes, and resource use of high school wrestling coaches. International Journal of Sport Nutrition, 7, 219-228.

Sundgot-Borgen, J. (1994). Risk and trigger factors for the development of eating disorders in female elite athletes. Medicine and Science in Sports and Exercise, 26, 414-419.

Thomas, S.J. (2004). Using web and paper questionnaires for data-based decision making: From design to interpretation of the results. Thousand Oaks, CA: Corwin Press.

Thompson, S.H., \& Gabriel, M. (2004). Risk factors for the female athlete triad among female collegiate and non-collegiate athletes. Physical Educator, 61, 200-212.

Trochim, W., \& Donnelly, J.P. (2007). The research methods knowledge base (3rd Edition). Mason, OH: Cengage Learning-Atomic Dog.

Troy, K., Hoch, A.Z., \& Stavrakos, J. (2006). Awareness and comfort in treating the female athlete triad: are we failing our athletes? WMJ-MADISON, 105, 21.

Turk, J.C. (1995). Collegiate coaches' knowledge of eating disorders. Unpublished master's thesis, University of North Carolina at Chapel Hill.

Turk, J.C., Prentice, W.E., Chappell, S., \& Shields Jr, E.W. (1999). Collegiate coaches' knowledge of eating disorders. Journal of athletic training, 34, 19-24.

Vaughan, J.L., King, K.A., \& Cottrell, R.R. (2004). Collegiate athletic trainers' confidence in helping female athletes with eating disorders. Journal of athletic training, 39, 71-76.

Wozney, L., Venkatesh, V., \& Abrami, P. (2006). Implementing computer technologies: Teachers' perceptions and practices. Journal of Technology and teacher education, 14, 173-207.

Zhu, W., Ennis, C. D., \& Chen, A. (1998) Many-faceted Rasch modelling expert judgment in test development. Measurement in Physical Education and Exercise Science, 2, 21-39.

\section{Authors' note}

Jillian E. Frideres and José M. Palao are affiliated with the Department of Physical Activity and Sport, University of Murcia (Universidad de Murcia), Spain.

Sue G. Mottinger is a retired Associate Professor, Department of Health \& Kinesiology, The University of Texas Pan American, Edinburg, Texas, United States.

\section{Corresponding author}

Jillian E. Frideres

Av. Reina Sofía, 32. Guadalupe, 30107, Murcia, Spain.

Phone: +34 9689041 34; Fax: +34 968308658

E-mail: jefrideres@gmail.com

Manuscript received on May 24, 2014

Manuscript accepted on March 10, 2015

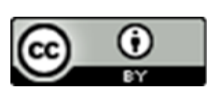

Motriz. The Journal of Physical Education. UNESP. Rio Claro, SP, Brazil - eISSN: 1980-6574 - under a license Creative Commons - Version 3.0 


\section{Appendix}

Questionnaire to measure coaches' female athlete triad knowledge

Please answer the following demographic and experiential questions. Unless otherwise noted, please choose one answer per question.

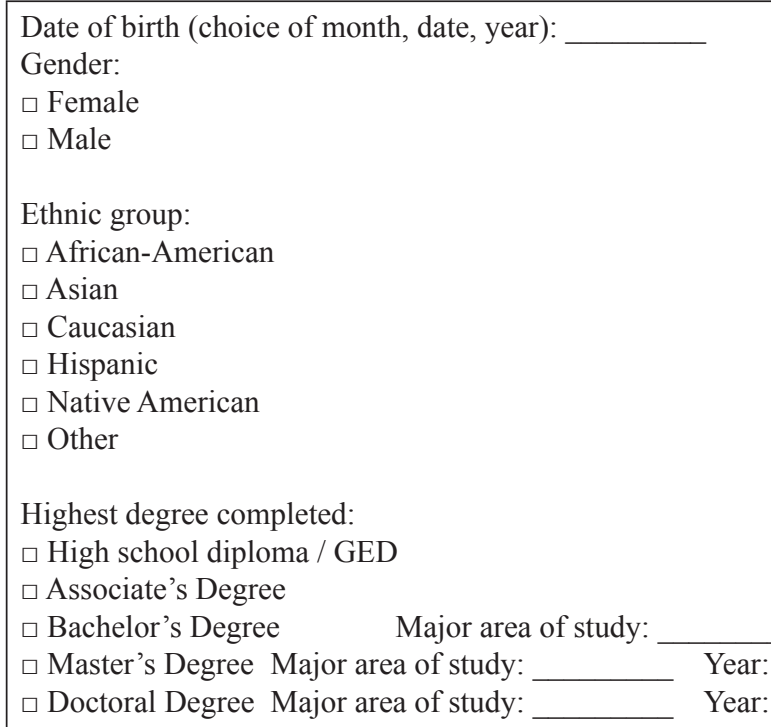

Sport(s) currently coaching at this level. Indicate the sport by checking the box then type the number of years* coaching this sport (if appropriate, choose more than one):

*Please enter years in a numerical format.

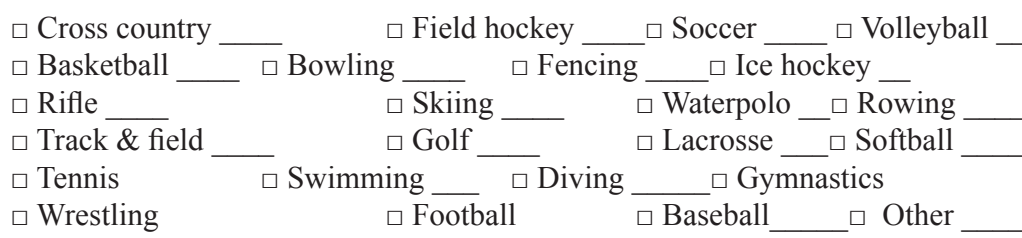




\begin{tabular}{|c|c|}
\hline $\begin{array}{l}\text { Number of coaches in your current program (including yourself): } \\
\text { Head coach } \\
\text { Assistant coach } \\
\text { Graduate assistant } \\
\text { Student (undergraduate) coach }\end{array}$ & \\
\hline Knowledge of the triad & \\
\hline $\begin{array}{l}\text { Please complete the following statements. Next to the answer please indicate the level of confidence you } \\
\text { following scale: } \\
1 \text { = Not at all confident } \\
2 \text { = Somewhat confident } \\
3 \text { = Confident } \\
4=\text { Completely sure } \\
\text { Example: There are_days in a week. Seven Confidence } 1 \quad 2 \quad 3 \quad 4\end{array}$ & in its correctness using the \\
\hline $\begin{array}{l}\text { The three components of the Female Athlete Triad are: } \\
\square \text { disordered eating, anemia, osteoporosis } \\
\square \text { anemia, amenorrhea, disordered eating } \\
\text { S amenorrhea, disordered eating, osteoporosis } \\
\square \text { amenorrhea, osteoporosis, anemia }\end{array}$ & Confidence $123 \quad 3 \quad 4$ \\
\hline $\begin{array}{l}\text { Those who can suffer from the triad are: } \\
\square \text { young adult female athletes who have started to menstruate } \\
\text { S any physically active female } \\
\square \text { adolescent female athletes }\end{array}$ & Confidence $123 \quad 3 \quad 4$ \\
\hline $\begin{array}{l}\text { Consequences of the triad can affect a female: } \\
\square \text { while she is still competing } \\
\square \text { as long as she remains physically active } \\
\text { S for the rest of her life }\end{array}$ & Confidence $1223 \quad 4$ \\
\hline $\begin{array}{l}\text { Signs and symptoms of the triad can include (choose all that apply): } \\
\text { S dizziness S S stress fracture S depression } \square \text { hyperactivity } \\
\text { S fatigue S low bone mineral density S mealtime anxiety } \\
\square \text { weight gain S irritability } \quad \text { S sore throat } \quad \text { S abdominal pain } \\
\text { S knuckle scars S dry hair \& skin } \square \text { hypertension } \square \text { tachycardia (high resting heart rate) S amenorrhea (lack } \\
\text { of menstruation) }\end{array}$ & Confidence $123 \quad 3 \quad 4$ \\
\hline $\begin{array}{l}\text { Risk factors of the triad include (choose all that apply): } \\
\text { S perfectionism } \quad \square \text { resilient } \\
\text { S chronic dieting } \quad \text { S training outside of scheduled practices } \\
\text { S low self-esteem } \quad \square \text { participation in strength training } \\
\text { S competitive nature } \quad \mathrm{S} \text { feeling pressure to lose weight to improve performance }\end{array}$ & Confidence 1223 \\
\hline $\begin{array}{l}\text { Please choose one answer (true, false, or don't know) for the following questions. Indicate the level of confid } \\
\text { correctness when answering true or false. Leave the confidence level blank when answering don't know. } \\
1 \text { = Not at all confident } \\
2 \text { = Somewhat confident } \\
3 \text { = Confident } \\
4 \text { = Completely sure } \\
\text { Example: There are } 25 \text { hours in a day. } \\
\text { True / False / Don't know Confidence } 123 \quad 34\end{array}$ & e you have in your answer's \\
\hline $\begin{array}{l}\text { Anorexia nervosa is characterized by the failure to maintain a normal weight for a person's age and height and } \\
\text { an intense fear of gaining weight. }\end{array}$ & $\begin{array}{l}\text { True / False / Don't know } \\
\text { Confidence } \begin{array}{llll}1 & 2 & 3 & 4\end{array}\end{array}$ \\
\hline Individuals with bulimia nervosa can be almost any weight and often experience body image disturbance. & $\begin{array}{l}\text { True / False / Don't know } \\
\text { Confidence } \begin{array}{llll}1 & 2 & 3 & 4\end{array}\end{array}$ \\
\hline Amenorrhea involves the absence of three or more consecutive menstrual cycles. & $\begin{array}{l}\text { True / False / Don't know } \\
\text { Confidence } \begin{array}{llll}1 & 2 & 3 & 4\end{array}\end{array}$ \\
\hline $\begin{array}{l}\text { Oligomenorrhea (six or fewer menstrual cycles per year) is not a major health concern as long as the athlete } \\
\text { is menstruating in the off-season. }\end{array}$ & $\begin{array}{l}\text { True / False / Don't know } \\
\text { Confidence } \begin{array}{llll}1 & 2 & 3 & 4\end{array}\end{array}$ \\
\hline Osteoporosis is characterized by low bone mineral density which affects overall bone health. & $\begin{array}{l}\text { True / False / Don't know } \\
\text { Confidence } \begin{array}{llll}1 & 2 & 3 & 4\end{array}\end{array}$ \\
\hline Osteopenia (lesser degree of bone loss than in osteoporosis), like osteoporosis, is directly affected by nutrition. & $\begin{array}{l}\text { True / False / Don't know } \\
\text { Confidence } \begin{array}{llll}1 & 2 & 3 & 4\end{array}\end{array}$ \\
\hline
\end{tabular}




\begin{tabular}{|c|c|}
\hline \multirow[t]{2}{*}{ Eating disorders can be fatal. } & True / False / Don't know \\
\hline & Confidence $1 \quad 2 \quad 3 \quad 4$ \\
\hline \multirow[t]{2}{*}{ Menstrual dysfunction in a college athlete generally has no bearing later in her adult life. } & True / False / Don't know \\
\hline & Confidence $1 \quad 2 \quad 3 \quad 4$ \\
\hline \multirow[t]{2}{*}{ Because of the impact of running on bone density, bone loss does not occur in many light-weight athletes. } & True / False / Don't know \\
\hline & Confidence $1 \quad 2 \quad 3 \quad 4$ \\
\hline \multirow[t]{2}{*}{ Repeated stress fractures should serve as a warning with regards to low bone mineral density. } & True / False / Don't know \\
\hline & Confidence $1 \quad 2 \quad 3 \quad 4$ \\
\hline \multirow[t]{2}{*}{ Eating disorders are caused exclusively by psychological problems. } & True / False / Don't know \\
\hline & Confidence $1 \quad 2 \quad 3 \quad 4$ \\
\hline \multirow{2}{*}{$\begin{array}{l}\text { If weight is a concern for the health of an athlete or for avoiding injury, giving the athlete a range of acceptable } \\
\text { weights or body fat compositions will help her to feel less pressure related to weight control. }\end{array}$} & True / False / Don't know \\
\hline & Confidence $123 \quad 3 \quad 4$ \\
\hline \multirow[t]{2}{*}{ Adequate levels of training and nutrition may cause some female athletes to stop menstruating. } & True / False / Don't know \\
\hline & Confidence $123 \quad 3 \quad 4$ \\
\hline \multirow[t]{2}{*}{ College-aged athletes who suffer from low bone density can generally recuperate all bone loss later in life. } & True / False / Don't know \\
\hline & Confidence $123 \quad 3 \quad 4$ \\
\hline \multirow[t]{2}{*}{ An athlete that suffers from the triad will have a sudden, apparent decrease in sport performance. } & True / False / Don't know \\
\hline & Confidence $1 \quad 2 \quad 3 \quad 4$ \\
\hline \multirow[t]{2}{*}{ As a coach, stressing an ideal weight helps an athlete understand how she can perform best in her sport. } & True / False / Don't know \\
\hline & Confidence $1 \quad 2 \quad 3 \quad 4$ \\
\hline \multirow[t]{2}{*}{ Joking comments made by others about one's weight can trigger disordered eating patterns in susceptible athletes. } & True / False / Don't know \\
\hline & Confidence $1 \quad 2 \quad 3 \quad 4$ \\
\hline \multirow{2}{*}{$\begin{array}{l}\text { Once an athlete has a confirmed case of one of the three components of the triad, screening for the other two } \\
\text { components should follow. }\end{array}$} & True / False / Don’t know \\
\hline & Confidence $1 \quad 2 \quad 3 \quad 4$ \\
\hline \multirow[t]{2}{*}{ It is an invasion of the athlete's privacy for the coaching staff to ask if her menstrual cycles are regular. } & True / False / Don't know \\
\hline & Confidence $123 \quad 3 \quad 4$ \\
\hline \multirow[t]{2}{*}{ A coach's influence on the athlete extends to the behaviors and beliefs of the coach regarding weight issues. } & True / False / Don't know \\
\hline & Confidence $123 \quad 3 \quad 4$ \\
\hline \multirow{2}{*}{$\begin{array}{l}\text { Prevention of the triad involves emphasizing to athletes the amount of macro- and micronutrients that they need } \\
\text { to compete as opposed to the foods they should avoid. }\end{array}$} & True / False / Don't know \\
\hline & Confidence $1 \quad 2 \quad 3 \quad 4$ \\
\hline \multirow{2}{*}{$\begin{array}{l}\text { An efficient and easy way for medical staff to screen for the triad involves using menstrual health history and } \\
\text { nutritional history questionnaires. }\end{array}$} & True / False / Don’t know \\
\hline & Confidence $1 \quad 2 \quad 3 \quad 4$ \\
\hline \multirow{2}{*}{$\begin{array}{l}\text { The coaching staff member or the athletic trainer with the best relationship with the athlete is the person who } \\
\text { should intervene when a case of the triad is suspected. }\end{array}$} & True / False / Don't know \\
\hline & Confidence $1 \quad 2 \quad 3 \quad 4$ \\
\hline \multirow[t]{2}{*}{ For health reasons, an athlete with a confirmed case of the female athlete triad must stop competing immediately. } & True / False / Don’t know \\
\hline & Confidence $1 \quad 2 \quad 3 \quad 4$ \\
\hline \multirow[t]{2}{*}{ When confronted about disordered eating or triad concerns, typically the athlete will be relieved and desire help. } & True / False / Don't know \\
\hline & Confidence $1 \quad 2 \quad 3 \quad 4$ \\
\hline \multirow[t]{2}{*}{ The intervention team should minimally involve a medical physician, dietician, and a psychiatrist or psychologist. } & True / False / Don't know \\
\hline & Confidence $1 \quad 2 \quad 3 \quad 4$ \\
\hline \multicolumn{2}{|c|}{ Finally, please complete the following questions about your program, choosing one answer unless otherwise noted. } \\
\hline $\begin{array}{l}\text { The athletic department currently has a policy in place that specifies what to do when we suspect that an athlete } \\
\text { suffers from one or more aspects of the female athlete triad }\end{array}$ & Yes / No / Don’t know \\
\hline $\begin{array}{l}\text { The athletic department currently has a policy in place that specifies what to do with a confirmed case of an } \\
\text { athlete with one or more aspects of the female athlete triad. }\end{array}$ & Yes / No / Don’t know \\
\hline $\begin{array}{l}\text { The athletic department currently has a policy in place that specifies what to do when we suspect that an athlete } \\
\text { suffers from one or more aspects of the female athlete triad }\end{array}$ & Yes / No / Don’t know \\
\hline $\begin{array}{l}\text { The athletic department currently has a policy in place that specifies what to do with a confirmed case of an } \\
\text { athlete with one or more aspects of the female athlete triad. }\end{array}$ & Yes / No / Don’t know \\
\hline The athletic department provides educational programming for the athletes about the female athlete triad. & Yes / No / Don’t know \\
\hline
\end{tabular}




\begin{tabular}{|c|c|c|c|}
\hline \multicolumn{3}{|c|}{ As a coach, I personally provide information for the athletes about the female athlete triad. } & Yes / No / Don’t know \\
\hline \multicolumn{3}{|c|}{$\begin{array}{l}\text { Although I do not personally speak to the athletes about it, I do provide educational programming about the } \\
\text { female athlete triad for them. }\end{array}$} & Yes / No / Don’t know \\
\hline \multicolumn{3}{|c|}{ I have received training on the subject of the Female Athlete Triad as a collective entity. } & Yes / No / Don’t know \\
\hline \multicolumn{3}{|c|}{$\begin{array}{l}\text { I have received training on at least one of the components of the Triad. } \\
\text { If so, which component(s)? } \\
\square \text { Amenorrhea } \\
\square \text { Disordered eating } \\
\square \text { Osteoporosis }\end{array}$} & Yes / No / Don’t know \\
\hline \multicolumn{4}{|c|}{$\begin{array}{l}\text { Indicate the type of continuing education you take part in at least once a year. } \\
\text { (check all that apply in general and specific to the triad) }\end{array}$} \\
\hline \multirow{2}{*}{ General } & \multicolumn{2}{|c|}{ Related to Triad } & \\
\hline & $\square$ & Athletic department programs & \\
\hline$\square$ & $\square$ & NCAA-sponsored programs & \\
\hline$\square$ & $\square$ & Review professional journals & \\
\hline$\square$ & $\square$ & Review sport/coaching-related magazines & \\
\hline$\square$ & $\square$ & Attend professional conferences & \\
\hline$\square$ & $\square$ & Read textbooks related to coaching, physiology, nutrition, etc. & \\
\hline$\square$ & $\square$ & Consult professionals (sports physician, dietician, etc.) & \\
\hline$\square$ & $\square$ & Search/read information online & \\
\hline & & other (please specify) & \\
\hline \multicolumn{3}{|c|}{$\square$ I do not participate in any continuing education. } & \\
\hline
\end{tabular}

